\title{
Effects of Dioxins and Polychlorinated Biphenyls on Thyroid Hormone Status of Pregnant Women and Their Infants
}

\author{
CORINE KOOPMAN-ESSEBOOM, DENNIS C. MORSE, NYNKE WEISGLAS-KUPERUS, \\ INEKE J. LUTKESCHIPHOLT, CORNELIS G. VAN DER PAAUW, \\ LOUIS G. M. T. TUINSTRA, ABRAHAM BROUWER, AND PIETER J. J. SAUER \\ Department of Pediatrics, Division of Neonatology, Erasmus University and University \\ Hospital/Sophia Children's Hospital, Rotterdam, The Netherlands [C.K.-E., N.W.-K., P.J.J.S.]; \\ Department of Toxicology, Agricultural University, Wageningen, The Netherlands [D.C.M., \\ I.J.L., A.B.]; TNO Nutrition and Food Research, Zeist, The Netherlands [C.G.V.d.P.]; and \\ DLO State Institute for Quality Control of Agricultural Products, \\ Wageningen, The Netherlands [L.G.M.T.T.]
}

\section{ABSTRACT}

Dioxins [polychlorinated dibenzo-p-dioxins (PCDD), dibenzofurans (PCDF)] and polychlorinated biphenyls (PCB) are potentially hazardous compounds. Animal studies have demonstrated that PCDD, PCDF, and PCB can alter thyroid hormone homeostasis. We investigated thyroid hormone levels in 105 mother-infant pairs. To estimate maternal and infant exposure, four nonplanar PCB congeners were measured in maternal plasma during the last month of pregnancy and in umbilical cord plasma. Seventeen PCDD and PCDF congeners, three planar PCB congeners, and 23 nonplanar $P C B$ congeners were measured in human milk. Higher PCDD, PCDF, and PCB levels in human milk, expressed as toxic equivalents, correlated significantly with lower plasma levels of maternal total triiodothyronine and total thyroxine, and with higher plasma levels of TSH in the infants in the 2 nd wk and $3 \mathrm{rd}$ mo after birth. Infants exposed to higher toxic equivalents levels had also lower plasma free thyroxine and total thy- roxine levels in the 2 nd wk after birth. We conclude that elevated levels of dioxins and PCB can alter the human thyroid hormone status. (Pediatr Res 36: 468-473, 1994)

Abbreviations
PCDD, polychlorinated dibenzo-p-dioxin
PCDF, polychlorinated dibenzofuran
PCB, polychlorinated biphenyl
TEQ, toxic equivalent
TEF, toxic equivalence factor
$\mathbf{T}_{\mathbf{3}}$, triiodothyronine
$\mathbf{T}_{\mathbf{4}}$, thyroxine
$\mathbf{T T}_{\mathbf{3}}$, total triiodothyronine
$\mathbf{T T}_{\mathbf{4}}$, total thyroxine
FT $_{\mathbf{4}}$, free thyroxine
TTR, transthyretin $_{\text {GC, gas chromatography }}$

PCDD and PCDF, summarized as dioxins, are tricyclic aromatic compounds. Because the number of chlorine atoms can vary between one and eight, there are potentially 75 different PCDD and 135 PCDF congeners. They are mainly formed as by-products during the synthesis of organochlorine chemicals and during the combustion of municipal and hazardous waste (1). PCB are a compilation of 209 possible congeners with different chlorine substitutions. Because of their unique physical properties and chemical stability, mixtures were used for diverse

Received January 14, 1994; accepted May 22, 1994.

Correspondence: C. Koopman-Esseboom, c/o P. J. J. Sauer, Sophia Children's Hospital, Dr. Molewaterplein 60, 3015 GJ Rotterdam, The Netherlands.

Supported by the Dutch Toxicology Research Promotion Programme and the Health Research Stimulation Programme. industrial applications, such as coolant fluids in transformers and dielectric fluids in capacitors, since 1930 (2). In the late $1970 \mathrm{~s}$, the production and the use of these compounds were banned because adverse health effects had become evident $(3,4)$. However, there are still significant quantities of PCB used in older transformers and capacitors.

Both dioxins and PCB are highly lipophilic and chemically stable compounds that accumulate in the food chain. The higher chlorinated congeners are more abundant in most biotic samples. For human beings the main sources of environmental exposure to these toxic compounds are dairy products, meat, and fish. They are stored mainly in the human adipose tissue, with elimination half-lives of 6 to $10 y(5)$. Small amounts of dioxins 
and PCB can reach the fetus by means of transplacental transport (6), whereas much higher levels reach the breast-fed infant. Dioxin levels can be especially high (10-100 pg TEQ/g milk fat) in human milk samples from highly industrialized, densely populated countries such as the Netherlands, Belgium, the United Kingdom, and Germany (7).

PCDD, PCDF, and PCB produce a wide spectrum of toxic effects in animals including body weight loss, immunotoxicity, thymic atrophy, hepatotoxicity, teratogenicity, carcinogenicity, and reproductive toxicity $(8,9)$. Furthermore, they can alter thyroid hormone status in laboratory animals. In rats and monkeys, exposure to PCDD, PCDF, or PCB generally results in decreased plasma $T_{4}$ levels, accompanied by increased concentrations of TSH (10-13). There is evidence that human exposure to these compounds may result in altered thyroid hormone status as well. Reduced serum $\mathrm{T}_{4}$ levels have been observed in transformer repair workers exposed to PCB (14). A recent study in a small group of breast-fed infants suggests that elevated levels of PCDD and PCDF in human milk might be associated with increases in plasma $\mathrm{TT}_{4}$ and TSH levels (15).

The aim of this study was to evaluate the effects of PCDD, PCDF, and PCB on the thyroid hormone status of pregnant women and their infants. This study is part of the Dutch PCB/Dioxin Study, a larger prospective longitudinal study on possible adverse health effects of these pollutants on human beings.

\section{METHODS}

The study group consisted of 105 healthy mother-infant pairs recruited between June 1990 and February 1992, living in Rotterdam and the surrounding area, which is a highly industrialized region in The Netherlands. Women were asked by their obstetrician or midwife to volunteer for the study. During the last month of pregnancy, mothers were visited at home for an explanation of the study protocol. The obstetric, delivery, and neonatal conditions were assessed by means of the obstetrical optimality scale (16). To establish an optimal study population, only infants born at term (37 to 42 wk of gestation) without congenital anomalies or diseases were included. All mother-infant pairs were of the Caucasian race. Pregnancy and delivery had to be completed without overt signs of serious illness or complications, and the infants had to be breast fed for at least $6 \mathrm{wk}$.

A blood sample was taken from the mothers in the last month of their pregnancy (36th to 40th wk) for the measurement of the PCB congeners $2,3^{\prime}, 4,4^{\prime}, 5$-pentachlorobiphenyl (PCB 118), 2,2', 3,4,4',5'-hexachlorobiphenyl (PCB 138), 2,2',4,4',5,5' -hexachlorobiphenyl (PCB 153), and 2,2',3,4,4',5,5'-heptachlorobiphenyl (PCB 180) (17). A blood sample of the umbilical cord was taken to measure the same PCB congeners as an indication of prenatal exposure. Blood was collected in a vacuum system EDTA tube, transported in a cooling pail, and centrifuged within $24 \mathrm{~h}$ during $15 \mathrm{~min}$ at $3000 \mathrm{rpm}$; plasma was stored at $-20^{\circ} \mathrm{C}$ until analysis. The detection of PCDD and PCDF in human tissues and milk became possible only in 1984. Because large amounts of blood (100-200 mL) are still needed to measure PCDD and PCDF levels, we analyzed them in human milk samples. Because these levels in human milk correlate well with the dioxin levels in adipose tissue (18), they are good indicators of maternal load and of prenatal and postnatal exposure of the breast-fed infant.

In the 2nd wk after delivery, the mothers collected a 24-h representative sample of breast milk by collecting before each feeding as much milk as possible from both breasts with a vacuum pump. An aliquot of $10 \%$ of each sample was pooled and stored in the refrigerator, the remainder was given to the infants in a bottle. After $24 \mathrm{~h}$ the milk was stored at $-20^{\circ} \mathrm{C}$ until analysis.

PCB congeners in plasma were measured by GC with electron capture detection (19). The human milk samples were analyzed for the 17 most abundant 2,3,7,8substituted PCDD and PCDF congeners and three planar PCB congeners [3, $3^{\prime}, 4,4^{\prime}$-tetrachlorobiphenyl (PCB 77), $3,3^{\prime}, 4,4^{\prime}, 5$-pentachlorobiphenyl (PCB 126), and $3,3^{\prime}, 4,4^{\prime}, 5,5^{\prime}$-hexachlorobiphenyl (PCB 169)] by GChigh-resolution mass spectrometry (20). Twenty-three nonplanar PCB congeners (PCB 28, 52, 66, 70, 99, 101, $105,118,128,137,138,141,151,153,156,170,177,180$, $183,187,194,195,202)(17)$ were measured by GC with electron capture detection (21).

To express the toxic potency of the mixture of dioxins and PCB in breast milk samples, the TEF approach was used $(22,23)$. A TEF value was assigned to the dioxin and dioxin-like PCB congeners to represent their relative toxic potency toward 2,3,7,8-tetrachlorodibenzo-pdioxin, the most toxic dioxin congener, which has a TEF value of one. By multiplying the concentration ( $\mathrm{pg} / \mathrm{g}$ milk fat) and TEF value, the TEQ of each congener was calculated (pg TEQ/g milk fat). By adding up the TEQ for all congeners, the total PCB-dioxin TEQ value was obtained. The TEQ sum of the dioxin and PCB congeners yielded a dioxin TEQ, planar-PCB TEQ (PCB 77, 126, and 169), and nonplanar-PCB TEQ (PCB 105, 118, 156, 170 , and 180 ). The other $\mathrm{PCB}$ congeners did not receive a TEF value because they have negligible dioxin-like activity.

$\mathrm{TT}_{4}, \mathrm{TT}_{3}, \mathrm{FT}_{4}$, and $\mathrm{TSH}$ were measured in maternal plasma during the last month of pregnancy (maternal pregnancy), 9 to $14 \mathrm{~d}$ after delivery (maternal postdelivery), in plasma of the umbilical cord (umbilical cord plasma), and in infants' plasma 9 to $14 \mathrm{~d}$ (infant $2 \mathrm{wk}$ ) as well as $3 \mathrm{mo}$ (infant $3 \mathrm{mo}$ ) after birth. TT $3, \mathrm{TT}_{4}, \mathrm{FT}_{4}$, and TSH were determined by chemiluminescence immunoassay, using standard Amerlite assay kits (Amersham, England).

The study protocol was approved by the medical ethical committee of the University Hospital Rotterdam/ Sophia Children's Hospital. Informed consent was given by the parents. 
Data analysis was performed by means of the statistical software package SPSS/PC. Means, medians, ranges, and standard deviations are reported in terms of original distributions. Spearman rank correlation coefficients were measured between $\mathrm{TT}_{4}, \mathrm{TT}_{3}, \mathrm{FT}_{4}$, TSH levels and individual PCB and dioxin congener levels as well as dioxin TEQ, PCB TEQ, and total PCB-dioxin TEQ levels. Because of the large number of analyses, a $p$ value $<$ 0.01 was estimated as being statistically significant. The Mann-Whitney test was used to analyze the significance of differences in thyroid hormone status between a low and high exposed breast-fed group; a $p$ value $<0.05$ was estimated as being statistically significant.

\section{RESULTS}

Of the initial 105 mother-infant pairs, 78 fulfilled all criteria and were included in the analysis. The median and range of $\mathrm{TT}_{3}, \mathrm{TT}_{4}, \mathrm{FT}_{4}$, and $\mathrm{TSH}$ levels in maternal and infant plasma are summarized in Table 1. One mother appeared to have an autoimmune hypothyroidism with high TSH levels. The levels of all the other mother-infant pairs were in the normal range for age-appropriate controls.

The mean level of the total PCB-dioxin TEQ in human milk was $74.86 \mathrm{pg} \mathrm{TEQ} / \mathrm{g}$ fat (SD 26.19, range 30.85154.21), the dioxin TEQ was $32.06 \mathrm{pg}$ TEQ/g fat (SD 11.26, range 12.44-76.43), the planar-PCB TEQ was $19.95 \mathrm{pg}$ TEQ/g fat (SD 8.54, range 6.39-51.11), and the nonplanar-PCB TEQ was $22.75 \mathrm{pg}$ TEQ/g fat (SD 8.96, range 8.52-58.19).

The significant correlation coefficients between TEQ levels and thyroid hormone plasma levels are summarized in Table 2. Higher levels of total PCB-dioxin TEQ, dioxin TEQ, and both planar- and nonplanar-PCB TEQ in human milk were significantly correlated with lower maternal plasma $\mathrm{TT}_{3}$ levels in the last month of pregnancy and with lower maternal plasma $\mathrm{TT}_{3}$ and $\mathrm{TT}_{4}$ levels in the 2nd wk after delivery. There was a trend toward a decline in the maternal plasma $\mathrm{TT}_{4}$ level in the last month of pregnancy with higher planar-PCB TEQ levels $(r=$ $-0.27, p<0.05$ ). There were no significant correlations with maternal plasma $\mathrm{FT}_{4}$ or TSH levels. The total PCB- dioxin TEQ, dioxin TEQ, and PCB TEQ levels demonstrated no significant correlations with $\mathrm{TT}_{3}, \mathrm{TT}_{4}, \mathrm{FT}_{4}$, or TSH levels in umbilical cord plasma. However, higher TEQ levels were significantly correlated with higher plasma TSH levels in the infants in the 2 nd wk and 3rd mo after birth.

Analyses of all individually measured PCDD, PCDF, and PCB congeners in human milk demonstrated that five PCDD congeners $(2,3,7,8$-tetrachlorodibenzo-p-dioxin, 1,2,3,7,8-pentachlorodibenzo-p-dioxin, 1,2,3,4,7,8hexachlorodibenzo-p-dioxin, 1,2,3,6,7,8-hexachlorodibenzo-p-dioxin, and 1,2,3,7,8,9-hexachlorodibenzo-pdioxin), three PCDF congeners (2,3,4,7,8-pentachlorodibenzofuran, 1,2,3,4,7,8-hexachlorodibenzofuran, 1,2,3,6,7,8-hexachlorodibenzofuran), two planar PCB congeners (PCB 126 and 169), and 12 nonplanar PCB congeners (PCB 105, 118, 128, 138, 153, 156, 170, 177, $180,183,187$, and 194) gave correlation coefficients with maternal or infants' thyroid hormone levels of the same order of magnitude as did the total PCB-dioxin TEQ, dioxin TEQ, and PCB TEQ levels. Higher levels of three nonplanar PCB congeners (PCB 137, 138, and 153) in human milk also correlated significantly with higher TSH levels in umbilical cord plasma $(r=0.31, p<0.01)$. Higher levels of PCB 118, 138, 153, and 180 in maternal and cord plasma correlated significantly with higher plasma TSH levels in the infants in the 2nd wk after birth.

In Table 3, the infants have been divided into a low [less than or equal to the median ( $30.75 \mathrm{pg} \mathrm{TEQ} / \mathrm{g}$ fat)] and a high (greater than the median) dioxin-exposed breast-fed group. The mean plasma $\mathrm{TT}_{4}$ level was significantly lower, and the mean plasma TSH level was significantly higher in the high exposed group in the $2 \mathrm{nd}$ wk after birth. In umbilical cord plasma and at $3 \mathrm{mo}$, only the mean plasma TSH level was significantly higher in the high dioxin-exposed breast-fed group $(8.5 \pm 6.0$ versus $11.6 \pm 8.0 \mu \mathrm{IU} / \mathrm{mL}, p<0.05$, and $1.6 \pm 0.6$ versus $2.3 \pm$ $1.0 \mu \mathrm{IU} / \mathrm{mL}, p<0.0004)$. When the infants were divided into low and high total PCB-dioxin TEQ-exposed breastfed groups (median $=72.43 \mathrm{pg} \mathrm{TEQ} / \mathrm{g}$ fat), the mean plasma $\mathrm{FT}_{4}$ level was also significantly lower in the high

Table 1. Median and range of plasma $T T_{4}, T T_{3}, F T_{4}$, and TSH levels of women in the last month of pregnancy and in the second week after delivery, of the umbilical cord and of infants in the 2nd wk and 3rd mo after birth*

\begin{tabular}{|c|c|c|c|c|c|}
\hline $\begin{array}{c}\text { Thyroid } \\
\text { hormone } \\
\text { parameter }\end{array}$ & $\begin{array}{c}\text { Maternal } \\
\text { pregnancy } \\
(n=78)\end{array}$ & $\begin{array}{l}\text { Maternal } \\
\text { after delivery } \\
(n=77)\end{array}$ & $\begin{array}{c}\text { Umbilical } \\
\text { cord } \\
(n=75) \\
\end{array}$ & $\begin{array}{c}\text { Infant } \\
\text { second week } \\
(n=78)\end{array}$ & $\begin{array}{c}\text { Infant } \\
\text { third month } \\
(n=78)\end{array}$ \\
\hline $\mathrm{TT}_{4}(\mathrm{nmol} / \mathrm{L})$ & $\begin{array}{c}152.2 \\
(89.3-210.3)\end{array}$ & $\begin{array}{c}134.7 \\
(77.2-190.1)\end{array}$ & $\begin{array}{c}127.1 \\
(78.3-187.3)\end{array}$ & $\begin{array}{c}168.7 \\
(83.9-245.7)\end{array}$ & $\begin{array}{c}139.3 \\
(72.3-214.5)\end{array}$ \\
\hline $\mathrm{TT}_{3}(\mathrm{nmol} / \mathrm{L})$ & $\begin{array}{c}2.5 \\
(1.9-3.9)\end{array}$ & $\begin{array}{c}2.1 \\
(1.4-2.5)\end{array}$ & $\begin{array}{c}1.0 \\
(0.6-1.9)\end{array}$ & $\begin{array}{c}2.9 \\
(2.0-4.3)\end{array}$ & $\begin{array}{c}3.0 \\
(2.0-3.8)\end{array}$ \\
\hline $\mathrm{FT}_{4}(\mathrm{pmol} / \mathrm{L})$ & $\begin{array}{c}11.7 \\
(8.0-16.0)\end{array}$ & $\begin{array}{c}15.3 \\
(11.6-21.5)\end{array}$ & $\begin{array}{c}16.0 \\
(12.0-23.7)\end{array}$ & $\begin{array}{c}23.7 \\
(17.2-34.1)\end{array}$ & $\begin{array}{c}17.2 \\
(12.4-24.5)\end{array}$ \\
\hline TSH $(\mu \mathrm{IU} / \mathrm{mL}) \dagger$ & $\begin{array}{c}1.4 \\
(0.02-18.0)\end{array}$ & $\begin{array}{c}1.0 \\
(0.03-6.6)\end{array}$ & $\begin{array}{c}10.0 \\
(2.8-33.7)\end{array}$ & $\begin{array}{c}2.3 \\
(0.7-9.8)\end{array}$ & $\begin{array}{c}2.0 \\
(0.8-6.0)\end{array}$ \\
\hline
\end{tabular}

* Values are median with range in parentheses.

† One mother with high TSH levels due to an autoimmune hypothyroidism included. 
Table 2. Spearman rank correlation coefficients between $T T_{3}$ and $T T_{4}$ levels in maternal plasma and TSH levels in infants' plasma and TEQ of dioxins, planar, and nonplanar PCB in human milk

\begin{tabular}{|c|c|c|c|c|c|}
\hline & $\begin{array}{c}\text { Maternal pregnancy } \\
\mathrm{TT}_{3} \\
(n=78)\end{array}$ & $\begin{array}{l}\text { Maternal after } \\
\text { delivery } \mathrm{TT}_{3} \\
(n=77)\end{array}$ & $\begin{array}{c}\text { Maternal after } \\
\text { delivery } \mathrm{TT}_{4} \\
(n=77)\end{array}$ & $\begin{array}{c}\text { Infant } 2 \text { nd wk } \\
\text { TSH } \\
(n=78)\end{array}$ & $\begin{array}{c}\text { Infant 3rd mo } \\
\text { TSH } \\
(n=78)\end{array}$ \\
\hline Dioxin TEQ & $-0.47^{*}$ & $-0.35 \dagger$ & $-0.34 \dagger$ & $0.38^{*}$ & $0.41^{*}$ \\
\hline Planar-PCB TEQ & $-0.39^{*}$ & $-0.38^{*}$ & $-0.33 \dagger$ & $0.37^{*}$ & $0.31 \dagger$ \\
\hline Nonplanar-PCB TEQ & $-0.36^{*}$ & $-0.33 \dagger$ & NS & $0.38^{*}$ & NS \\
\hline Total PCB-Dioxin TEQ & $-0.46^{*}$ & $-0.37^{*}$ & $-0.35 \dagger$ & $0.40^{*}$ & $0.39^{*}$ \\
\hline
\end{tabular}

${ }^{*} p \leq 0.001$.

$+p \leq 0.01$

exposed group in the 2 nd wk after birth $(24.6 \pm 3.5$ versus $23.0 \pm 3.3 \mathrm{pmol} / \mathrm{L}, p<0.05$ ).

\section{DISCUSSION}

In this study, we found mean dioxin levels in human milk (32 pg TEQ/g fat) that are elevated compared with the mean dioxin levels of countries in northern and southern Europe such as Sweden and Spain, which have levels of 20 and $13 \mathrm{pg}$ TEQ/g fat, respectively. The dioxin and PCB levels are comparable to the levels in other highly industrialized countries in western Europe, such as Belgium, the United Kingdom, and Germany (7). Except for one mother with high TSH levels, plasma $\mathrm{TT}_{3}, \mathrm{TT}_{4}, \mathrm{FT}_{4}$, and TSH levels of all mother-infant pairs were in the normal range. We demonstrated that higher dioxin and PCB TEQ levels in human milk were significantly correlated with lower maternal plasma $\mathrm{TT}_{3}$ and $\mathrm{TT}_{4}$ levels and with higher infant plasma TSH levels in the 2nd wk and 3 rd mo after birth. Twenty-two individual PCDD, PCDF, and PCB congener levels measured in human milk gave correlation coefficients with maternal and infant thyroid hormone levels of the same order of magnitude as did the TEQ levels. It is impossible from this study to define the dioxin or PCB congeners that really have an effect on thyroid hormone levels because there are associations between the congener patterns in humans (18), who are exposed mainly to one source, food.

Reduced serum $\mathrm{T}_{4}$ levels have also been described in transformer repair workers exposed to PCB (14). Murai et al. (24) described an increase in serum $T_{3}$ and $T_{4}$ levels in adults $16 \mathrm{y}$ after exposure to high levels of PCB and PCDF via food compared with nonexposed controls. Serum $\mathrm{FT}_{4}, \mathrm{TSH}$, and $\mathrm{T}_{4}$ binding globulin levels were not altered. However, they did not find significant correlations between PCB levels and thyroid hormone levels in serum. The results might be different from our data because PCB were measured as total PCB level, which is less accurate compared with our congener-specific analysis. Furthermore, a short exposure to high PCB levels might have different effects on thyroid hormone parameters compared with a long-term background exposure. Pluim et al. (15) divided a group of 38 healthy newborns into a high and low dioxin-exposed breast-fed group compared with the median dioxin TEQ $(29.0 \mathrm{pg}$ TEQ/g fat) in human milk. In agreement with our study, they found a significantly higher mean plasma TSH level $11 \mathrm{wk}$ after birth in the high exposed group. In contrast to our study, they found significantly higher mean $\mathrm{TT}_{4}$ levels in the infants' plasma at 1 and 11 wk after birth.

In general, the effects of dioxins and PCB in our human study resemble the effects on plasma $\mathrm{TT}_{3}, \mathrm{TT}_{4}, \mathrm{FT}_{4}$, and TSH levels in rats and monkeys $(10-13,25)$. In these animals, dioxins and PCB cause a reduction of plasma $\mathrm{TT}_{4}$ and $\mathrm{FT}_{4}$ levels and a concomitant increase in TSH levels. Plasma $\mathrm{TT}_{3}$ levels are usually much less affected by dioxins and PCB. In rats, hydroxy-metabolites of PCB cause a decline in plasma $\mathrm{TT}_{4}$ levels. The metabolites have a marked structural resemblance to $\mathrm{T}_{4}$ and occupy the $\mathrm{T}_{4}$ binding pocket on TTR, the most important plasma binding protein for $T_{4}$ in rats (26). In in vitro studies, hydroxy-metabolites of PCB and dioxins also compete with $\mathrm{T}_{4}$ for human TTR (27). The binding capacity of $\mathrm{T}_{4}$ binding globulin, which is the most important binding protein for $\mathrm{T}_{4}$ in human plasma, does not seem to be influenced by PCB or dioxins (28). Although the competition for binding to TTR is unlikely to be the cause for a decreased plasma $\mathrm{TT}_{4}$ and $\mathrm{TT}_{3}$ level in humans, it might still be of importance for $\mathrm{T}_{4}$ passage through the bloodbrain barrier. Herbert et al. (29) postulated that, also in humans, $\mathrm{T}_{4}$ transport from the circulation into the cere-

Table 3. Plasma $T T_{3}, T T_{4}, F T_{4}$, and TSH levels in infants in the 2nd wk of life in a low and high dioxin-exposed breast-fed group

\begin{tabular}{|c|c|c|c|c|c|}
\hline & \multicolumn{2}{|c|}{$\begin{array}{l}\text { Low dioxin-exposed } \\
(\leq 30.75 \mathrm{pg} \text { TEQ } / \mathrm{g} \text { fat })\end{array}$} & \multicolumn{2}{|c|}{$\begin{array}{l}\text { High dioxin-exposed } \\
(>30.75 \mathrm{pg} \text { TEQ/g fat })\end{array}$} & \multirow[b]{2}{*}{$p^{*}$} \\
\hline & Mean \pm SD & $n$ & Mean \pm SD & $n$ & \\
\hline $\mathrm{TT}_{3}(\mathrm{nmol} / \mathrm{L})$ & $2.9 \pm 0.5$ & 39 & $2.9 \pm 0.5$ & 39 & 0.66 \\
\hline $\mathrm{TT}_{4}(\mathrm{nmol} / \mathrm{L})$ & $177.5 \pm 39.2$ & 39 & $159.9 \pm 31.6$ & 39 & 0.04 \\
\hline $\mathrm{FT}_{4}(\mathrm{pmol} / \mathrm{L})$ & $24.3 \pm 3.4$ & 39 & $23.1 \pm 3.4$ & 39 & 0.16 \\
\hline $\mathrm{TSH}(\mu \mathrm{IU} / \mathrm{mL})$ & $1.9 \pm 0.8$ & 39 & $2.6 \pm 1.5$ & 39 & 0.004 \\
\hline
\end{tabular}

\footnotetext{
* Mann-Whitney test.
} 
brospinal fluid is based on the binding of $T_{4}$ to TTR produced in the choroid plexus. Hydroxy-metabolites of PCB, which can also be measured in human tissues (30), could cause a decline in the local brain $\mathrm{T}_{4}$ level by interrupting the $\mathrm{T}_{4}$ transport on TTR.

Besides affecting plasma thyroid hormone transport, dioxins and $\mathrm{PCB}$ can also alter peripheral $\mathrm{T}_{4}$ metabolism. In rats, dioxins and PCB decrease plasma $\mathrm{TT}_{4}$ levels by inducing hepatic uridine diphosphate-glucuronyltransferase. As a consequence, the biliary excretion of $\mathrm{T}_{4}$ glucuronide is enhanced $(11,31)$. Morse et al. (32) demonstrated that decreases in plasma $\mathrm{TT}_{4}$ and $\mathrm{FT}_{4}$ levels, induced by PCB, were accompanied by increases of type II $T_{4} 5^{\prime}$-deiodinase, the enzyme responsible for the deiodination of $T_{4}$ to biologically active $T_{3}$ in the brain of adult, fetal, and neonatal rats.

Small amounts of maternal thyroid hormone pass the placental barrier (33) and could be important for the early development of the fetus, which is able to produce its own thyroid hormones from the 12th wk on. Further research is necessary to elucidate the mechanism by which dioxins and PCB alter the thyroid hormone status in humans.

We did not find significant correlations between PCB levels in cord plasma or dioxin levels in human milk and $\mathrm{TT}_{3}, \mathrm{TT}_{4}, \mathrm{FT}_{4}$, or TSH levels in umbilical cord plasma. However, when we related all individual PCB congener levels measured in human milk with the thyroid hormone levels in umbilical cord plasma, higher PCB 137, 138, and 153 congener levels correlated significantly with higher TSH levels in cord plasma. There are a few explanations for these differences in results. The PCB levels we measured in umbilical cord plasma were about 5 times lower compared with the levels in maternal plasma, about 20 times lower compared with PCB levels in human milk on volume base, and close to the detection limit. Secondly, the PCB levels in plasma were expressed on volume base and the dioxin and PCB levels in human milk on lipid base. Because dioxins and PCB are bound mainly to lipids, in which contents can vary, PCB levels in plasma expressed on lipid base might be more representative.

The higher plasma TSH levels in the 2nd wk and 3rd mo after birth may be a sustained reaction to prenatal exposure to dioxins and PCB to remain euthyroid. An alternative explanation for these increases in TSH levels is additional postnatal exposure to dioxins and PCB through breast feeding. When neonatal plasma $\mathrm{TT}_{3}, \mathrm{TT}_{4}$, $\mathrm{FT}_{4}$, and TSH levels were divided into low and high dioxin-exposed breast-fed groups, plasma $\mathrm{TT}_{4}$ was significantly lower and TSH significantly higher in the high exposed group in the 2 nd wk after birth. When the thyroid hormone levels were divided into a low and high total PCB-dioxin TEQ-exposed breast-fed group, plasma $\mathrm{FT}_{4}$ was also significantly lower in the high exposed group. At the age of $3 \mathrm{mo}$, we found no significant differences in the infants' plasma $\mathrm{TT}_{3}, \mathrm{TT}_{4}$, or $\mathrm{FT}_{4}$ levels, although TSH was still significantly higher. The infants' thyroid hormone production could have come into a new balance by TSH stimulation.

We demonstrated that Dutch levels of dioxins and PCB correlate with alterations of the human thyroid hormone status. Sufficient levels of $T_{4}$, which is deiodinated into active $T_{3}$ on the tissue level, are necessary for normal brain development (34). Although the thyroid hormone levels were found to be in the normal range, the small changes observed in this study might be of influence on the development of the fetus and infant; this will be the subject of further study.

\section{REFERENCES}

1. Rappe C, Andersson R, Bergqvist PA, Brohede C, Hansson M, Kjeller LO, Lindström G, Marklund S, Nygren M, Swanson SE, Tysklind M, Wiberg K 1987 Overview of environmental fate of chlorinated dioxins and dibenzofurans, sources, levels and isomeric pattern in various matrices. Chemosphere 16:1603-1618

2. De Voogt P, Brinkman UAT 1989 Production, properties and usage of polychlorinated biphenyls. In: Kimbrough RD, Jensen AA (eds) Halogenated Biphenyls, Terphenyls, Naphthalenes, Dibenzodioxins and Related Products. Elsevier, Amsterdam, pp 3-45

3. Kuratsune M, Yoshimura T, Matsuzaka J, Yamaguchi A 1972 Epidemiological study on Yusho, a poisoning caused by ingestion of rice oil contaminated with a commercial brand of polychlorinated biphenyls. Environ Health Perspect $1: 119-128$

4. Rogan WJ, Gladen BC, Hung K-L, Koong S-L, Shih L-Y, Taylor JS, Wu Y-C, Yang D, Ragan NB, Hsu C-C 1988 Congenital poisoning by polychlorinated biphenyls and their contaminants in Taiwan. Science 241:334-336

5. Michalek JE, Tripathi RC, Caudill SP, Pirkle JL 1992 Investigation of TCDD half-life heterogeneits in veterans of Operation Ranch Hand. J Toxicol Environ Health 35:29-38

6. Schecter A, Päpke O, Ball M 1990 Evidence for transplacental transfer of dioxins from mother to fetus: chlorinated dioxins and dibenzofuran levels in livers of stillborn infants. Chemosphere 21:1017-1022

7. World Health Organization 1989 Levels of PCBs, PCDDs, and PCDFs in Breast Milk: Results of WHO-Coordinated Interlaboratory Quality Control Studies and Analytical Field Studies. Environmental Health Series 34. FADL, Copenhagen

8. Safe S 1984 Polychlorinated biphenyls (PCBs) and polybrominated biphenyls (PBBs): biochemistry, toxicology, and mechanism of action. Crit Rev Toxicol 13:319-395

9. Skene SA, Dewhurst IC, Greenberg M 1989 Polychlorinated dibenzo-pdioxins and polychlorinated dibenzofurans: the risks to human health. A review. Human Toxicol 8:173-203

10. Ness DK, Schantz SL, Moshtaghian J, Hansen LG 1993 Effects of perinatal exposure to specific PCB congeners on thyroid hormone concentrations and thyroid histology in the rat. Toxicol Lett 68:311-323

11. Bastomsky $\mathrm{CH} 1977$ Enhanced thyroxine metabolism and high uptake goiters in rats after a single dose of 2,3,7,8-tetrachlorodibenzo-p-dioxine. Endocrinology 101:292-296

12. Van den Berg KJ, Zurcher C, Brouwer A 1988 Effects of 3,4,3',4'. tetrachlorobiphenyl on thyroid function and histology in marmoset monkeys. Toxicol Appl Pharmacol 41:77-86

13. Brewster DW, Elwell MR, Birnbaum LS 1988 Toxicity and disposition of 2,3,4,7,8-pentachlorodibenzofuran (4PeCDF) in the rhesus monkey (Macaca mulatta). Toxicol Appl Pharmacol 93:231-246

14. Emmett EA, Maroni M, Jefferys J, Schmith J, Levin BK, Alvares A 1988 Studies of transformer repair workers exposed to PCBs. II: Results of clinical laboratory investigations. Am J Ind Med 14:47-62

15. Pluim HJ, Koppe JG, Olie K, Van der Slikke JW, Vulsma T, Kok JH, Vulsma T, van Tijn D, de Vijlder JJM 1992 Effects of dioxins on thyroid function in newborn babies. Lancet 339:1303

16. Touwen BCL, Huisjes HJ, Jurgens-vd Zee, Bierman-van Eendenburg MEC Smrkovsky M, Olinga AA 1980 Obstetrical condition and neonatal neurological morbidity. An analysis with the help of the optimality concept. Early Hum Dev 4/3:207-228

17. Ballschmiter K, Bacher R, Mennel A, Fischer R, Riehle U, Swerev M 1992 The determination of chlorinated biphenyls, chlorinated dibenzodioxins and chlorinated dibenzofurans by GC-MS. J High Resolut Chromatogr 15:260-270

18. Jensen AA 1991 Transfer of chemical contaminants into human milk. In: Jensen AA, Slorach SA (eds) Chemical Contaminants in Human Milk. CRC Press, Boca Raton, FL, pp 9-19

19. Burse VW, Korver MP, Needham LL, Lapeza CR, Boozer EL, Head SL 1989 Gas chromatographic determination of polychlorinated biphenyls (as Aroclor 1254) in serum: collaborative study. J Assoc Off Anal Chem 72:649659

20. Van Rhijn JA, Traag WA, Van de Spreng PG, Tuinstra LGMT 1993 Simultaneous determination of planar chlorobiphenyls and polychlorinated 
dibenzo-p-dioxins and -furans in Dutch milk using isotope dilution and gas chromatography-high-resolution mass spectrometry. J Chromatogr 630:297306

21. Tuinstra LGMT, Van Rhijn JA, Traag WA, Van de Spreng P, Zuidema T, Horstman HJ 1993 Method for the determination of dioxins, planar and other PCBs in human milk. In: Fiedler H, Frank H, Hutzinger O, Parzefall W, Riss A, Safe S (eds) Organohalogen Compounds 11, Analytical Methods Formation and Sources. Federal Environmental Agency, Austria, pp 181-183

22. NATO/CCMS Pilot Study on International Information Exchange on Dioxins and Related Compounds. International Toxicity Equivalency Factor (I-TEF). Method of Risk Assessment for Complex Mixtures of Dioxins and Related Compounds. Report number 176

23. Ahlborg UG, Becking GC, Birnbaum LS, Brouwer A, Derks HJGM, Feeley M, Golor G, Hanberg A, Larsen JC, Liem AKD, Safe SH, Schlatter C, Waern F, Younes M, Yrjänheikki E 1994 Toxic equivalency factors for dioxin-like PCBs. Report on a WHO-ECEH and IPCS consultation, December 1993. Chemosphere 28:6

24. Murai K, Okamura K, Tsuji H, Kajiwara E, Watanabe H, Akagi K, Fujishina 1987 Thyroid function in "Yusho" patients exposed to polychlorinated biphenyls. Environ Res 44:179-187

25. Van Birgelen A, Van der Kolk J, Fase K, Poiger H, Brouwer A, Van den Berg M 1992 Toxicity and biochemical potencies of polychlorinated biphenyl congeners relative to 2,3,7,8-tetrachlorodibenzo-p-dioxin in three months feeding studies in the rat. In: Organohalogen Compounds 10, Toxicology, Epidemiology, Risk Assessment and Management. Painotalo Miktor, Helsinki, pp 373-376

26. Brouwer A, Van den Berg KJ 1986 Binding of a metabolite of $3,4,3^{\prime}, 4^{\prime}$. tetrachlorobiphenyl to transthyretin reduces serum vitamin A transport by inhibiting the formation of the protein complex carrying both retinol and thyroxin. Toxicol Appl Pharmacol 85:301-312
27. Lans MC, Klasson-Wehler E, Willemsen M, Meussen E, Safe S, Brouwer A 1993 Structure-dependent, competitive interaction of hydroxy-polychlorobiphenyls, dibenzo-p-dioxins and dibenzofurans with human transthyretin. Chem Biol Interact 88:7-21

28. Lans MC, Spiertz C, Brouwer A, Koeman JH 1994 Different competition of thyroxine binding to transthyretin and thyroxine-binding globulin by hydroxyPCBs, PCDDs and PCDFs. Eur J Pharmacol 270:129-136

29. Herbert J, Wilcox JN, Pham K-TC, Fremeau RT, Zeviani M, Dwork A, Soprano DR, Makover A, Goodman, DeWitt S, Zimmerman EA, Roberts JL, Schon EA 1986 Transthyretin: a choroid plexus-specific transport protein in human brain. Neurology 36:900-911

30. Klasson-Wehler E, Kuroki H, Athanasiadou M, Bergman $\AA 1992$ Selective retention of hydroxylated PCBs in blood. In: Organohalogen Compounds 10 , Toxicology, Epidemiology, Risk Assessment and Management. Painotalo Miktor, Helsinki, pp 121:122

31. Beetstra JB, Van Engelen JGM, Karels P, Van der Hoek HJ, De Jong M, Docter R, Krenning EP, Henneman G, Brouwer A, Visser TJ 1991 Thyroxine and 3,3',5-triiodothyronine are glucuronidated in rat liver by different uridine diphosphate-glucuronyltransferases. Endocrinology 128:741-746

32. Morse DC, Groen D, Veerman M, Van Amerongen CJ, Koëter HBWM, Smits van Prooije AE, Visser TJ, Koeman JH, Brouwer A 1993 Interference of polychlorinated biphenyls in hepatic and brain thyroid hormone metabolism in fetal and neonatal rats. Toxicol Appl Pharmacol 122:27-33

33. Vulsma T, Gons MH, De Vijlder JJM 1989 Maternal-fetal transfer of thyroxine in congenital hypothyroidism due to a total organification defect or thyroid agenesis. N Engl J Med 321:13-16

34. Porterfield SP, Hendrich CE 1993 The role of thyroid hormones in prenatal and neonatal neurological development: current perspectives. Endocr Rev 14:94-106 